\title{
ОСОБЛИВОСТІ СТАНОВЛЕННЯ СОЦІАЛЬНОГО ІНТЕЛЕКТУ ОСОБИСТОСТІ ПІЗНЬОГО ЮНАЦЬКОГО ВІКУ
}

\author{
Олена Старинська \\ кандидат психологічних наук, доцент, \\ доцент кафедри прикладної психології та логопедії \\ Бердянський державний педагогічний університет \\ 71100, Україна, м. Бердянськ, вул. Шмідта, 4 \\ el.starinskaya@gmail.com, http://orcid.org/0000-0003-4601-4152
}

\begin{abstract}
Анотація
У статті подано результати емпіричного вивчення особливостей соціального інтелекту особистості пізнього юнацького віку, порівняно із соціальним інтелектом особистості зрілого віку. Презентовано психологічний смисл феномена «соціальний інтелект». За нашим розумінням, соціальний інтелект є складним комплексом здатностей особистості до пізнання і розв'язання завдань, що визначають успішність іiі взаємодій з іншими людьми у соціумі. Описано організацію і методи емпіричного дослідження. Метою дослідження $\epsilon$ емпіричне вивчення особливостей становлення соціального інтелекту особистості пізнього юнацького віку. Досягненню визначеної мети сприяло застосування Тесту соціального інтелекту авторів Дж. Гілфорда і М. О’Саллівен в адаптації О. Михайлової. Проведено порівняльний аналіз результатів вивчення загального показника соціального інтелекту і його основних конструктів (здатності розуміти різні життєві ситуації, прояви невербальної й вербальної поведінкової експресії та прогнозування поведінки інших людей) у респондентів пізнього юнацького і зрілого віку. Емпірично 3'ясовано, що особистість пізнього юнацького віку частіше проявляє нижче середнього і середній рівні здатності до пізнання соціальної поведінки інших людей та адекватного розуміння невербальних і вербальних проявів їх поведінки, на противагу особистості зрілого віку. Особистість пізнього юнацького віку нечасто здатна правильно проаналізувати і спрогнозувати стратегію успішної поведінки, як власної, так і інших людей, порівняно з особистістю зрілого віку. Не завжди особистість пізнього юнацького віку здатна адекватно зрозуміти прояви вербальної та невербальної поведінкової експресії інших людей, на противагу особистості зрілого віку. В особистості пізнього юнацького віку значно нижче розвинута здатність прогнозувати поведінку інших людей, порівняно 3 особистістю зрілого віку. Виявлені особливості становлення соціального інтелекту досить часто заважають успішності соціальних взаємодій особистості пізнього юнацького віку, на противагу особистості зрілого віку.
\end{abstract}

Ключові слова: соціальний інтелект, здатність, особистість, пізній юнацький вік, зрілий вік.

\section{Вступ}

Інтенсифікація входження України до соціокультурного простору Європи потребує нагальних інноваційних змін в усіх суспільних сферах держави і передусім - в освіті. Важливість модернізації сфери освіти у напрямку розвитку соціальних компетентностей учнівської та студентської молоді з метою її успішної соціалізації задекларовано в Законі 
України «Про освіту». Успішність адаптації та взаємодій підростаючого покоління у соціумі зумовлюється рівнем соціального інтелекту. 3 огляду на зазначене проблема розвитку соціального інтелекту учнів і студентів в умовах освітнього процесу є досить актуальною і соціально значущою для сучасної вітчизняної психологічної науки.

Вивченню процесу становлення соціального інтелекту особистості на різних етапах онтогенезу присвячено низку наукових робіт сучасних зарубіжних i вітчизняних психологів.

Особливості становлення соціального інтелекту особистості молодшого шкільного віку досліджувалися в межах вікової та педагогічної (А. Мельник) і спеціальної (І. Володіна) психології.

В роботі А. Мельник розкрито результати теоретичного й емпіричного вивчення становлення соціального інтелекту дітей різного шкільного віку і молодших школярів, зокрема. За позицією психологині, соціальний інтелект - це здатність особистості розуміти, адекватно оцінювати і прогнозувати власні вчинки й поведінку в різних життєвих ситуаціях, а також інших людей. Рівень соціального інтелекту людей є основним чинником ефективності взаємодій між ними. В структурі соціального інтелекту особистості вона виокремила такі здатності: до соціальних знань, запам'ятовування імен і облич інших людей, соціальної інтуїції, перцепції та прогнозування (когнітивний компонент); соціальної чутливості, емпатії й саморегуляції (емоційний компонент); соціальної взаємодії та адаптивності (поведінковий компонент). За результатами емпіричного вивчення соціального інтелекту другокласників 8-річного віку дослідниця виявила їх високий рівень здатності до емпатії та середній - до саморегуляції. А також низькі рівні здатності до запам'ятовування імен і облич інших людей, соціального прогнозування, соціальних взаємодій, соціальної інтуїції та соціальної адаптивності (Мельник, 2012).

В дослідженні І. Володіної висвітлено особливості становлення соціального інтелекту молодших школярів із порушенням інтелектуального розвитку, порівняно 3 їх ровесниками без цих порушень. На думку вченої, соціальний інтелект є такою здатністю особистості пізнавати й розкривати соціально-психологічні якості соціальних об'єктів пізнання, що характеризує специфічність структури ії розумового досвіду як суб'єкта міжособистісних взаємодій i пізнання. Емпірично вона виявила високий рівень інтегрованості й диференційованості міжособистісного пізнання в учнів четвертого класу iз порушенням інтелектуального розвитку та учнів другого класу без цих порушень. Iзпоміж респондентів із високим рівнем інтегрованості та диференційованості міжособистісного пізнання виявлено більше дівчаток, порівняно 3 хлопчиками. Також констатовано, що високий рівень здатності дитини молодшого шкільного віку 3 порушенням інтелектуального розвитку до міжособистісної децентрації, який передбачає адекватне розуміння мотивів поведінки та емоцій інших людей, компенсує певні недоліки компонентів її соціального інтелекту (Володина, 2004).

Особливості становлення соціального інтелекту особистості підліткового віку вивчалися науковцями в межах вікової та педагогічної (А. Мельник) і спеціальної (О. Ватіна, О. Сгорова) психології. Вивчаючи становлення соціального інтелекту підлітків віком 11-12 років, А. Мельник емпірично констатувала в них високий рівень емпатійності. А також - середній рівень здатності до запам'ятовування імен і облич інших людей, 
соціального прогнозування, соціальної адаптивності, соціальних взаємодій і саморегуляції та низький рівень соціальної інтуїції (Мельник, 2012).

В дослідженні О. Ватіної доведено негативний вплив низького рівня пізнавальної активності молодших підлітків на розвиток їхньої соціальної спрямованості та успішність соціальних взаємодій із ровесниками і дорослими. Чинниками такого негативного впливу визначено недостатній розвиток у підлітків із порушенням інтелектуального розвитку соціально-перцептивних компетенцій, соціальних знань, соціальної спрямованості, специфічності їхнього емоційного розвитку. Зазначені особливості соціального й емоційного розвитку цих молодших підлітків заважають їхньому правильному орієнтуванню у соціальних взаємодіях з іншими людьми та адекватному розумінню їхньої поведінки (Ватина, 2006).

У своєму дослідженні О. Сгорова емпірично зафіксувала вплив низького рівня соціального інтелекту підлітків із порушенням інтелектуального розвитку на їх міжособистісні взаємодії. Неспроможність останніх аналізувати проблемні ситуації соціальних взаємодій, розуміти емоції та прогнозувати поведінку інших людей призводить до підвищення рівня їхньої агресивності та схильності до девіантної поведінки. У підлітків без порушень інтелектуального розвитку такого впливу не виявлено (Егорова, 2014).

Особливості становлення соціального інтелекту особистості раннього юнацького (чи старшого шкільного) віку досліджувалися у руслі вікової та педагогічної (А. Мельник) і спеціальної (Н. Коновалова і Н. Соломахо) психології.

Вивчаючи соціальний інтелект старших школярів, А. Мельник емпірично зафіксувала високий рівень низки його складників. А саме - здатності до запам'ятовування імен і облич інших людей, емпатійності, соціальної адаптивності, здатності до саморегуляції, здатності до соціальних взаємодій. А також - середній рівень соціального прогнозування і соціальної інтуїції (Мельник, 2012).

В дослідженні Н. Коновалової та Н. Соломахо емпірично виявлено, що старшокласників із порушенням інтелектуального розвитку, які навчаються і виховуються у дитячих будинках, характеризує високий рівень здатності розв'язувати міжособистісні конфлікти. Як і їхні ровесники з порушенням інтелектуального розвитку, що виховуються у сім'ях, вони, хоча й ознайомлені з нормами поведінки у соціумі, однак вирізняються низьким рівнем розуміння рольових взаємодій між людьми. Загалом дослідники виявили сформованість практичного рівня соціального інтелекту, соціальну незрілість і недостатню соціальну адаптованість учнів старших класів із порушенням інтелектуального розвитку (Коновалова \& Соломахо, 2002).

Особливості становлення соціального інтелекту особистості пізнього юнацького (чи студентського) віку вивчалися у межах загальної психології Так, у роботі О. Милославської розкрито гендерні особливості взаємозв'язків соціального інтелекту з міжособистісною залежністю студентів. Психолог емпірично виявила значущий взаємозв'язок між окремими складниками соціального інтелекту та здоровою залежністю i прагненням до автономії у дівчат, що може сприяти їхній самодостатності у взаємодіях 3 іншими людьми. Також вона зафіксувала взаємозв'язок між сильною потребою юнаків в емоційній підтримці з боку значущих інших і здатністю прогнозувати результати поведінки людей, які їх оточують (Милославська, 2019). 
Особливості становлення соціального інтелекту особистості зрілого віку в окремому професійному контексті вивчалися у межах загальної психології. Дослідження Е. Івашкевича присвячено соціальному інтелекту педагогів. За розумінням психолога, соціальний інтелект педагога є складним особистісним утворенням, до структури якого належать комунікативна і прогностична компетентності. Він емпірично виявив, що рівень розвитку соціального інтелекту педагогів зумовлено їхнім типом гендерної ідентичності, психотипом особистості та стилем професійної діяльності. Також учений зафіксував домінування середнього рівня невербальної поведінкової експресії та розуміння смислу висловлювань соціального змісту в директорів і педагогів закладів дошкільної освіти (Івашкевич, 2018; Ivashkevych \& Yatsjuryk, 2019).

Здійснений теоретичний аналіз сучасних наукових досліджень засвідчив, що зарубіжні та вітчизняні психологи вивчали окремі аспекти проблеми становлення соціального інтелекту особистості на різних вікових етапах. За межами їхнього інтересу залишилося питання про особливості розвитку соціального інтелекту особистості в пізній юності, що й зумовило вибір мети статті.

Мета дослідження: емпірично вивчити особливості становлення соціального інтелекту особистості в пізньому юнацькому віці. Завдання дослідження: 1) визначення психологічного смислу феномена «соціальний інтелект»; 2) організація та проведення емпіричного дослідження з досліджуваними пізнього юнацького віку на базі вітчизняних закладів вищої освіти; 3) організація та проведення емпіричного дослідження 3 респондентами зрілого віку; 4) здійснення порівняльного аналізу одержаних результатів із застосуванням методів математичної статистики.

\section{Методи дослідження}

3 огляду на наукові позиції вчених (Гилфорд, 1965; Торндайк, 2003; Ушаков, 2004; Goleman, 2006), ми розуміємо соціальний інтелект як складний комплекс здатностей особистості до пізнання і розв'язання завдань, що визначають успішність ії взаємодій 3 іншими людьми у соціумі.

Для досягнення поставленої мети і розв’язання визначених завдань проводилося емпіричне дослідження. У дослідженні брали участь 94 респонденти пізнього юнацького віку і 86 - зрілого віку. Контингент досліджуваних склали студенти Бердянського державного педагогічного університету і Національного педагогічного університету імені М. П. Драгоманова (середній вік - 18,6 років) і працюючі представники різних професій із міст Бердянськ і Київ (середній вік - 45,3 років).

Для вивчення соціального інтелекту респондентів використовувався тест авторів Дж. Гілфорда і М. О’Саллівен в адаптації О. Михайлової (Михайлова, 2001). За його допомогою було виявлено рівні (низький, нижче середнього, середній, вище середнього, високий) загального показника соціального інтелекту респондентів i його основних конструктів. Такими конструктами $є$ їх здатність розуміти різні життєві ситуації (субтест 1), невербальну (субтест 2) і вербальну (субтест 3) поведінкову експресію і прогнозувати поведінку (субтест 4) щодо інших людей. У процесі статистичної обробки одержаних кількісних даних застосовувався критерій $\varphi^{*}$-кутового перетворення Р. Фішера (Климчук, 2009). Значення цього критерію при $\mathrm{p} \leq 0,01$ позначено *, а при $\mathrm{p} \leq 0,05$ - **. 


\section{Результати та дискусії}

Спочатку на рис. 1 подано результати вивчення загального показника соціального інтелекту досліджуваних.

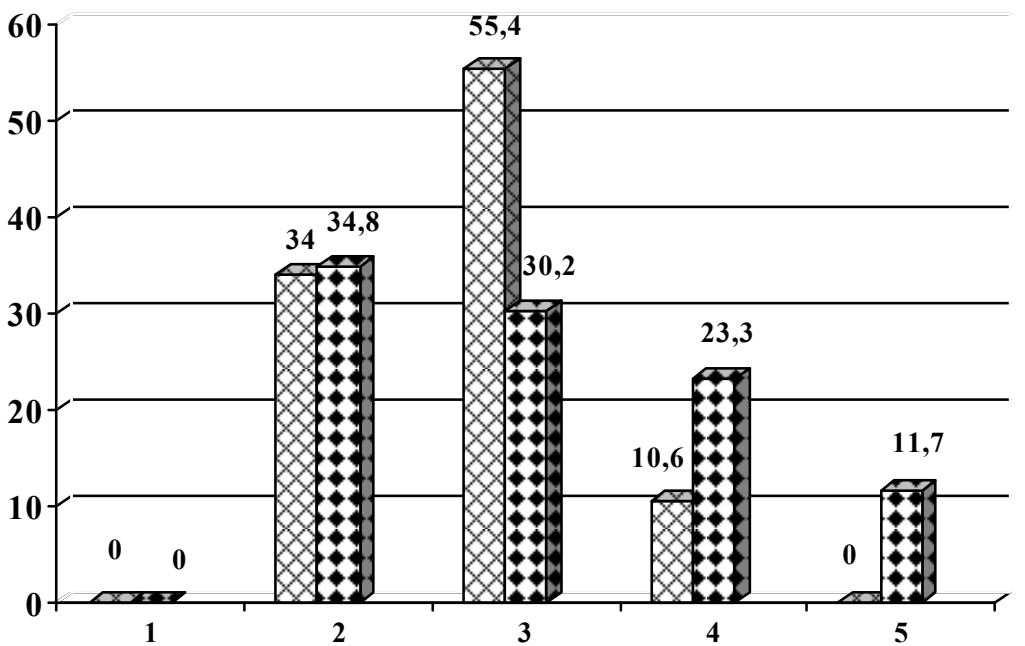

囚 Юнацький вік

园 Зрілий вік

\section{Рис. 1. Рівні загального показника соціального інтелекту особистості пізнього юнацького і зрілого віку (\%)}

Примітка. Рівні загального показника соціального інтелекту респондентів позначено так: 1 - низький, 2 - нижче середнього, 3 - середній, 4 - вище середнього, 5 - високий.

Як видно 3 рис. 1, низького рівня загального показника соціального інтелекту в досліджуваних не виявлено. Рівень, що є нижче середнього і характеризує таку ж здатність до пізнання поведінкових проявів інших людей, виявлено в майже однакової кількості респондентів пізнього юнацького (34\%) і зрілого $(34,8 \%)$ віку. Статистичні відмінності між кількісними даними на цьому рівні незначущі $-\varphi^{*}=0,127$. Середній рівень помічено у значно більшої кількості досліджуваних пізнього юнацького $(55,4 \%)$ і в меншої - зрілого $(30,2 \%)$ віку. Статистичні відмінності кількісних даних цього рівня виявилися значущими $\left(\varphi^{*}=3,438^{*}\right)$. Одержані відмінності пояснюються тим, що всі досліджувані пізнього юнацького віку є студентами закладів вищої освіти, а частина респондентів зрілого віку такої освіти не мають.

Відмінності на середньому рівні пояснюються більшими кількісними даними респондентів зрілого віку на наступних, вищих рівнях. А саме - рівень вище середнього зафіксовано в 23,3\% досліджуваних зрілого і в 10,6\% - пізнього юнацького віку. Відмінності кількісних даних на цьому рівні є статистично значущими $\left(\varphi^{*}=2,305^{* *}\right)$. Натомість високий рівень виявлено лише в 11,7\% респондентів зрілого віку. На противагу пізньому юнацькому, в зрілому віці виявлено більшу кількість респондентів із вищими рівнями загального показника соціального інтелекту, що пояснюється багатим життєвим досвідом останніх.

Отже, порівняно зі зрілим віком, особистість пізнього юнацького віку в багатьох ситуаціях проявляє нижче середнього і середній рівні здатності до пізнання соціальної поведінки інших людей та адекватного розуміння невербальних і вербальних проявів 
їхньої поведінки. Натомість у небагатьох виявлені вище середнього і високий рівні. Це сприяє успішності окремих соціальних взаємодій особистості цього віку.

Нижче презентовано результати дослідження основних конструктів соціального інтелекту респондентів. Рівні здатності досліджуваних розуміти різні ситуації життя інших людей подано на рис. 2.

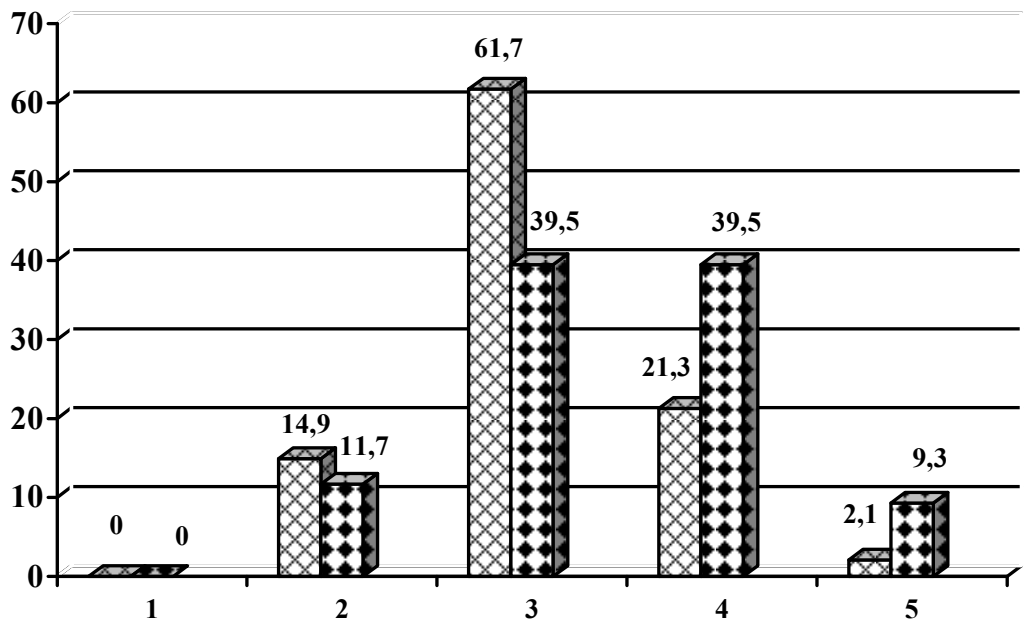

\begin{tabular}{l} 
囚 Юнацький вік \\
ФЗрілий вік \\
\hline
\end{tabular}

\section{Рис. 2. Рівні здатності особистості пізнього юнацького і зрілого віку розуміти різні ситуації життя інших людей (\%)}

Примітка. Рівні здатності особистості розуміти різні ситуації життя інших людей позначено так: 1 - низький, 2 - нижче середнього, 3 - середній, 4 - вище середнього, 5 високий.

3 рис. 2 видно, що низького рівня здатності розуміти різні ситуації життя інших людей у досліджуваних не зафіксовано. Рівень, що є нижче середнього, виявлено у дещо більшої кількості респондентів пізнього юнацького $(14,9 \%)$ і в меншої - зрілого $(11,7 \%)$ віку. Відмінності кількісних даних на цьому рівні не $\epsilon$ статистично значущими $\left(\varphi^{*}=0,657\right)$. Середній рівень визначено в значно більшої кількості досліджуваних пізнього юнацького $(61,7 \%)$ і меншої - зрілого (39,5\%) віку. Відмінності між кількісними даними цього рівня є статистично значущими $\left(\varphi^{*}=3,002^{*}\right)$.

На наступних, вищих рівнях більші кількісні дані констатовано у респондентів зрілого віку. Так, рівень вище середнього помічено в 39,5\% досліджуваних зрілого і в $21,3 \%$ - пізнього юнацького віку. Відмінності кількісних даних цього рівня статистично значущі $\left(\varphi^{*}=2,681^{*}\right)$. Високий рівень властивий 9,3\% респондентів зрілого і 2,1\% пізнього юнацького віку. Відмінності між кількісними даними на цьому рівні $\epsilon$ статистично значущими $\left(\varphi^{*}=2,205^{* *}\right)$.

Як бачимо, здатність розуміти різні ситуації життя інших людей краще розвинута в особистості зрілого віку, порівняно з юнацьким, що пов'язано з більшим життєвим досвідом старших людей. На противагу зрілому, особистість пізнього юнацького віку здатна правильно проаналізувати і спрогнозувати стратегію успішної поведінки, як інших людей, так і власну в небагатьох ситуаціях. 
На рис. 3 презентовано результати вивчення здатності досліджуваних розуміти невербальну поведінкову експресію інших людей.

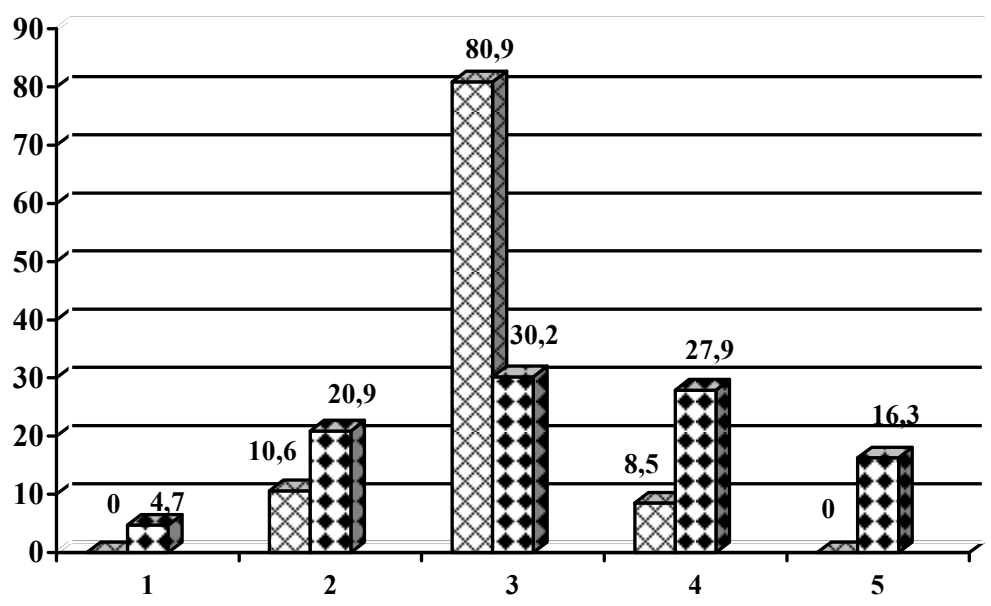

囚 Юнацький вік
УЗрілий вік

\section{Рис. 3. Рівні здатності особистості пізнього юнацького і зрілого віку розуміти невербальну поведінкову експресію інших людей (\%)}

Примітка. Рівні здатності особистості розуміти невербальну поведінкову експресію інших людей позначено так: 1 - низький, 2 - нижче середнього, 3 - середній, 4 - вище середнього, 5 - високий.

Як помітно з рис. 3, низький рівень здатності розуміти невербальну поведінкову експресію інших людей характерний лише для 4,7\% респондентів зрілого віку. Рівнем, що $\epsilon$ нижче середнього, вирізняється значно менша кількість досліджуваних пізнього юнацького (10,6\%) і більша - зрілого (20,9\%) віку. Відмінності між кількісними даними цього рівня є статистично значущими $\left(\varphi^{*}=1,923 * *\right)$. Середній рівень зафіксовано в переважної кількості респондентів пізнього юнацького $(80,9 \%)$ віку, порівняно зі зрілим (30,2\%). Відмінності кількісних даних цього рівня статистично значущі ( $\left.\varphi^{*}=7,191 *\right)$.

На наступних, вищих рівнях більші кількісні дані знову виявлено в досліджуваних зрілого віку. Рівень вище середнього - в 27,9\% респондентів зрілого і в 8,5\% пізнього юнацького віку. Відмінності між кількісними даними на цьому рівні статистично значущі $\left(\varphi^{*}=3,492^{*}\right)$. Натомість високий рівень - лише у 16,3\% респондентів зрілого віку.

Отже, порівняно зі зрілим, не кожна особистість пізнього юнацького віку здатна адекватно розуміти невербальну поведінкову експресію інших людей, що в багатьох ситуаціях заважає їі успішним соціальним взаємодіям.

На рис. 4 подано результати дослідження здатності респондентів розуміти вербальну поведінкову експресію інших людей. 


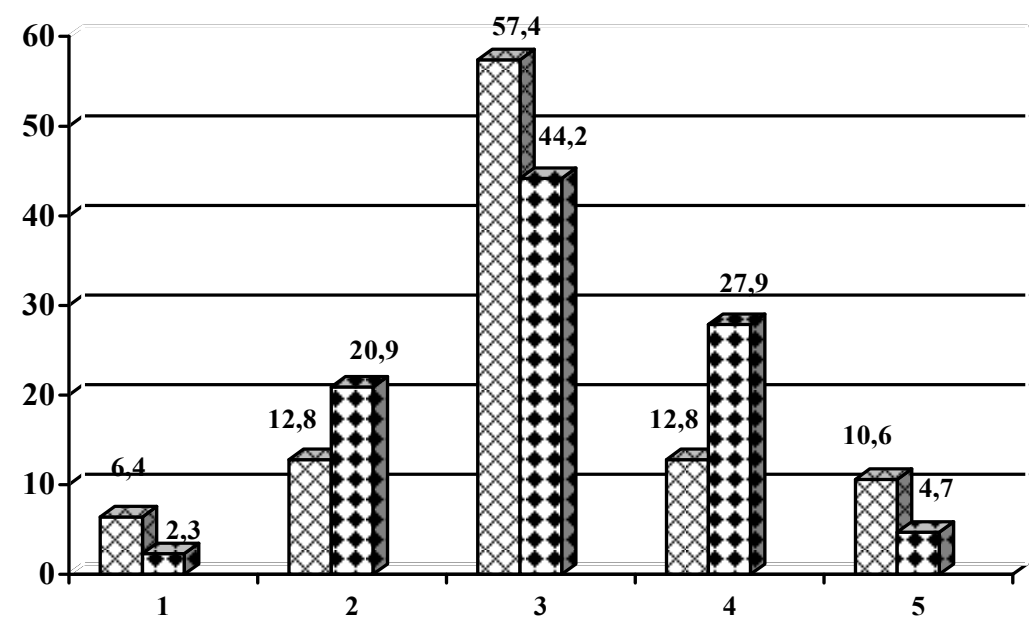

Юнацький вік

ШЗрілий вік

Рис. 4. Рівні здатності особистості пізнього юнацького і зрілого віку розуміти вербальну поведінкову експресію інших людей (\%)

Примітка. Рівні здатності особистості розуміти вербальну поведінкову експресію інших людей позначено так: 1 - низький, 2 - нижче середнього, 3 - середній, 4 - вище середнього, 5 - високий.

Як видно з рис. 4, низький рівень здатності розуміти вербальну поведінкову експресію інших людей виявлено у більшої кількості респондентів пізнього юнацького $(6,4 \%)$ та у меншої $(2,3 \%)$ зрілого віку. Відмінності кількісних даних на цьому рівні не $\epsilon$ статистично значущими $\left(\varphi^{*}=1,394\right)$. Рівень, що $\epsilon$ нижче середнього, зафіксовано у меншої кількості досліджуваних пізнього юнацького (12,8\%) і більшої - зрілого (20,9\%) віку. Відмінності між кількісними даними на цьому рівні також статистично незначущі $\left(\varphi^{*}=1,461\right)$. Середній рівень виявлено також у більшої кількості респондентів пізнього юнацького $(57,4 \%)$ і в меншої - зрілого (44,2\%) віку. Відмінності кількісних даних на цьому рівні є статистично значущими ( $\left.\varphi^{*}=1,769^{* *}\right)$.

На наступному рівні, що є вище середнього, менші кількісні дані виявлено в досліджуваних пізнього юнацького (12,8\%) і значно більші - зрілого (27,9\%) віку. Відмінності між кількісними даними на цьому рівні також статистично значущі $\left(\varphi^{*}=2,553^{*}\right)$. Проте високий рівень помічено у більшої кількості респондентів пізнього юнацького $(10,6 \%)$ і в дещо меншої - зрілого (4,7\%) віку. Відмінності кількісних даних на цьому рівні статистично незначущі $\left(\varphi^{*}=1,515\right)$.

Отож, як і вербальну, так і невербальну поведінкову експресію інших людей не кожна особистість пізнього юнацького віку здатна краще розуміти, порівняно 3 особистістю зрілого віку.

На рис. 5 презентовано результати вивчення здатності досліджуваних прогнозувати поведінку інших людей. Помітно, що низький рівень здатності прогнозувати поведінку інших людей виявлено лише в $2,1 \%$ досліджуваних пізнього юнацького віку. Рівень, що є нижче середнього, зафіксовано в більшої кількості респондентів пізнього юнацького $(29,8 \%)$ і меншої - зрілого (18,6\%) віку. Відмінності кількісних даних цього рівня статистично значущі $\left(\varphi^{*}=1,763^{* *}\right)$. Середній рівень також визначено в дещо більшої 
кількості досліджуваних пізнього юнацького (49\%) і меншої - зрілого (41,8\%) віку. Відмінності між кількісними даними на цьому рівні $\epsilon$ статистично незначущими $\left(\varphi^{*}=0,945\right)$.

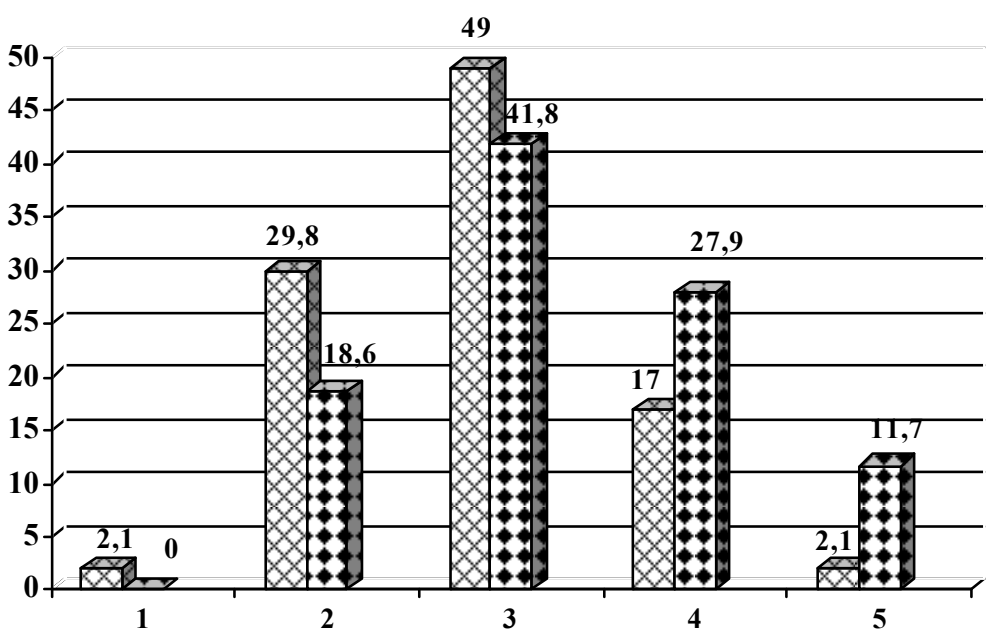

囚 Юнацький вік ๑ Зрілий вік

\section{Рис. 5. Рівні здатності особистості пізнього юнацького і зрілого віку прогнозувати поведінку інших людей (\%)}

Примітка. Рівні здатності особистості прогнозувати поведінку інших людей позначено так: 1 - низький, 2 - нижче середнього, 3 - середній, 4 - вище середнього, 5 - високий.

На наступних, вищих рівнях більші кількісні дані помічено в респондентів зрілого віку. Зокрема, рівень вище середнього виявлено в 27,9\% досліджуваних зрілого і в 17\% пізнього юнацького віку. Відмінності кількісних даних цього рівня статистично значущі $\left(\varphi^{*}=1,858^{* *}\right)$. Високий рівень констатовано у $11,7 \%$ респондентів зрілого і в 2,1\% пізнього юнацького віку. Відмінності між кількісними даними на цьому рівні $\epsilon$ статистично значущими $\left(\varphi^{*}=2,707^{*}\right)$.

Отже, порівняно зі зрілим віком, здатність прогнозувати поведінку інших людей гірше розвинута в особистості пізнього юнацького віку, що, вочевидь, зумовлено ії небагатим життєвим досвідом.

\section{Висновки}

Проведене емпіричне дослідження дозволило зробити такі висновки. На противагу особистості зрілого віку, особистість пізнього юнацького віку частіше проявляє нижчі (нижче середнього і середній) рівні здатності до пізнання соціальної поведінки інших людей та адекватного розуміння невербальних і вербальних проявів їхньої поведінки. Особистість пізнього юнацького віку здатна правильно проаналізувати і спрогнозувати стратегію власної успішної поведінки та інших людей у небагатьох ситуаціях. Не кожна особистість пізнього юнацького віку продемонструвала адекватне розуміння вербальної та невербальної поведінкової експресії інших людей. В особистості пізнього юнацького віку гірше розвинута здатність прогнозувати поведінку інших людей. Зазначене перешкоджає 
успішності соціальних взаємодій особистості цього віку. Перспективу подальших досліджень вбачаємо у вивченні особливостей становлення соціального інтелекту особистості пізнього юнацького віку з порушеннями інтелектуального розвитку.

\section{Література}

1. Ватина, Е.В. (2006). Организачионно-педагогические условия формирования сочиального интеллекта учащихся младшего подросткового возраста $c$ недоразвитием познавательной деятельности. (Дис. канд. психол. наук). Екатеринбург.

2. Володина, И.С. (2004). Специфика развития социильного интеллекта младших школьников с умственной отсталостью. (Дис. канд. психол. наук). Санкт-Петербург.

3. Гилфорд, Дж. (1965). Три стороны интеллекта. Психология мышления. Москва : Прогресс.

4. Егорова, О.Н. (2014). Роль социального интеллекта в формировании девиантного поведения у умственно отсталых подростков. (Дис. канд. психол. наук). СанктПетербург.

5. Івашкевич, Е.3. (2018). Психологія сочіального інтелекту педагога. (Дис. д-ра психол. наук). Київ.

6. Климчук, В.О. (2009). Математичні методи у психологї: навч. посібн. для студ. психол. спец. Київ : Освіта України.

7. Коновалова, Н.Л., \& Соломахо, Н.В. (2002). Особенности социального интеллекта у умственно отсталых старшеклассников. А.И. Юрьев, Л.А. Цветкова (Общ. ред.), Ананьевские чтения: психология и политика (Тезисы научно-практической конференции «Ананьевские чтения - 2002») (с. 71-72). Санкт-Петербург : Изд-во СПб ун-та.

8. Лобанов, А.П. (Ред.). (2003). Социальный интеллект: Проблемы исследования и диагностики. А.П. Лобанов, О.Н. Подунова, \& О.Н. Кунгурцева (Сост.). Минск : БГПУ.

9. Мельник, А.А. (2012). Розвиток сочүіального інтелекту дітей шкільного віку. (Дис. канд. психол. наук). Харків.

10. Милославська, О.В. (2019). Соціальний інтелект і міжособистісна залежність у студентів: гендерний аспект. Теорія і практика сучасної психологіï, 1 (1), 76-80. Режим доступу : http://tpsp-journal.kpu.zp.ua/archive/1_2019/part_1/17.pdf

11. Михайлова (Алешина), Е.С. (2001). Диагностика соииального интеллекта. СанктПетербург : ГП ИМАТОН.

12. Ушаков, Д.В. (2004). Социальный интеллект как вид интеллекта. Д.В. Люсин \& Д.В. Ушаков. (Ред.), Социальный интеллект: теория, измерение, исследования (с. 1129). Москва : Институт психологии РАН.

13. Ivashkevych, E. \& Yatsjuryk, A. (2019). Psycholinguistic Study of Functioning of Cognitions and Metacognitions on the Levels of Social Intelligence. Psycholinguistics, 25(1), 90-106. https://doi.org/10.31470/2309-1797-2019-25-1-90-106

14. Goleman, D. (2006). Social intelligence. The New Science of Human Relationships. New York : Bantam Books.

\section{References}

1. Vatina, E.V. (2006). Organizatsionno-pedagogicheskie usloviia formirovaniia sotsialnogo intellekta uchashchikhsia mladshego podrostkovogo vozrasta s nedorazvitiem poznavatelnoi deiatelnosti [Organizational and pedagogical conditions for the formation of social intelligence of students of younger adolescents with underdevelopment of cognitive activity]. Candidate's thesis. Ekaterinburg [in Russian]. 
2. Volodina, I. S. (2004). Spetsifika razvitiia sotsialnogo intellekta mladshikh shkolnikov s umstvennoi otstalostiu [The specifics of the development of social intelligence of younger students with mental retardation]. Candidate's thesis. Sankt-Peterburg [in Russian].

3. Gilford, Dzh. (1965). Tri storony intellekta. Psikhologiia myshleniia [Three sides of intelligence. The psychology of thinking.]. Moscow : Progress [in Russian].

4. Egorova, O.N. (2014). Rol sotsialnogo intellekta $v$ formirovanii deviantnogo povedeniia $u$ umstvenno otstalykh podrostkov [The role of social intelligence in the formation of deviant behavior in mentally retarded teenagers]. Candidate's thesis. Sankt-Peterburg [in Russian].

5. Ivashkevych, E.Z. (2018). Psykholohiia sotsialnoho intelektu pedahoha [Psychology of the teacher's social intelligence]. Doctor's thesis. Kyiv [in Ukrainian].

6. Klymchuk, V.O. (2009). Matematychni metody u psykholohii [Mathematical methods in psychology]. Kyiv : Osvita Ukrainy [in Ukrainian].

7. Konovalova, N.L. \& Solomakho, N.V. (2002). Osobennosti sotsialnogo intellekta u umstvenno otstalykh starsheklassnikov [Features of social intelligence in mentally retarded high school students]. In A.I. Iurev, L.A. Tsvetkova (Eds.), Proceedings from Ach' 02: Ananevskie chteniia: psikhologiia $i$ politika (Tezisy nauchno-prakticheskoi konferentsii "Ananevskie chteniia - 2002») - Ananiev readings: psychology and politics (Theses of the scientific-practical conference "Ananiev readings - 2002») (pp. 71-72). Sankt-Peterburg : Izd-vo SPb un-ta [in Russian].

8. Lobanov, A.P. (Eds.). (2003). Sotsialnyi intellekt: Problemy issledovaniia i diagnostiki [Social intelligence: Problems of research and diagnosis]. A.P. Lobanov, O.N. Podunova, \& O.N. Kungurtseva (Comp.). Minsk : BGPU [in Russian].

9. Melnyk, A.A. (2012). Rozvytok sotsialnoho intelektu ditei shkilnoho viku [Development of social intelligence of school children]. Candidate's thesis. Kharkiv [in Ukrainian].

10. Myloslavska, O.V. (2019). Sotsialnyi intelekt i mizhosobystisna zalezhnist u studentiv: hendernyi aspekt [Social Intelligence and Interpersonal Addiction in Students: A Gender Aspect]. Teoriia $i$ praktyka suchasnoi psykholohii - Theory and practice of modern psychology, 1(1), 76-80. Retrieved from http://tpspjournal.kpu.zp.ua/archive/1 2019/part 1/17.pdf [in Ukrainian].

11. Mikhailova (Aleshina), E.S. (2001). Diagnostika sotsialnogo intellekta [Diagnostics of social intelligence]. Sankt-Peterburg : GP IMATON. [in Russian].

12. Ushakov, D.V. (2004). Sotsialnyi intellekt kak vid intellekta [Social intelligence as a kind of intelligence]. D.V. Liusin \& D.V. Ushakov (Eds.), Sotsialnyi intellekt: teoriia, izmerenie, issledovaniia - Social intelligence: theory, measurement, research (pp. 11-29). Moscow : Institut psikhologii RAN [in Russian].

13. Ivashkevych, E. \& Yatsjuryk, A. (2019). Psycholinguistic Study of Functioning of Cognitions and Metacognitions on the Levels of Social Intelligence. Psycholinguistics, 25(1), 90-106. https://doi.org/10.31470/2309-1797-2019-25-1-90-106

14. Goleman, D. (2006). Social intelligence. The New Science of Human Relationships. New York : Bantam Books. 


\title{
PECULIARITIES OF DEVELOPMENT OF SOCIAL INTELLIGENCE PERSONALITY \\ OF LATER YOUTH AGE \\ Olena Starynska \\ PhD in Psychology, Associate Professor, Associate Professor of the Department \\ of Applied Psychology and Speech Therapy \\ Berdiansk State Pedagogical University \\ 4, Schmidt Str., Berdiansk, Zaporizhzhia region, 71100, Ukraine \\ el.starinskaya@gmail.com, http://orcid.org/0000-0003-4601-4152
}

\begin{abstract}
The article presents the results of empirical study of the features of social intelligence of late young age, in comparison with the social intelligence of mature age. The psychological meaning of the phenomenon of «social intelligence» is presented. In our understanding, social intelligence is a complex of personality's abilities to know and solve problems that determine the success of its interactions with other people in society. The organization and methods of empirical research are described. The purpose of the study is to empirically study the peculiarities of the development of social intelligence of a personality of late young age. The achievement of this goal was facilitated by the application of the social intelligence test by authors J. Guilford and M. O'Sullivan in the adaptation of O. Mykhailova. A comparative analysis of the results of studying the general index of social intelligence and its basic constructs (ability to understand different life situations, manifestations of non-verbal and verbal behavioral expression and prediction of other people's behavior) was conducted in the respondents' of late young age and mature age. It has been empirically established that the personality of late adolescence is more likely to exhibit lower than average and average levels of knowledge of other people's social behavior and adequate understanding of non-verbal and verbal manifestations of their behavior, as opposed to mature age. The personality of late young age is infrequently unable to properly analyze and predict the strategy of successful behavior, both of one's own and that of others, compared to that of a mature age. It is not always the personality of late young age that can adequately understand the manifestations of verbal and non-verbal behavioral expression of other people, as opposed to the personality of mature age. In the late adolescence, the ability to predict other people's behavior is much lower than that of a mature personality. The established peculiarities of the formation of social intelligence often hinder the success of social interactions of a personality of late adolescence, as opposed to a person of mature age.
\end{abstract}

Keywords: social intelligence, ability, personality, late young age, mature age.

Подано 16.12.2019

Рекомендовано до друку 20.12.2019 